\title{
ANALISIS BERITA HOAKS DI KORPUS SOSIAL MEDIA GUNA MENGEMBANGKAN MODEL "KAPAK HOAKS" (KEMANDIRIAN PEMBACA MENGANALISIS KONTEN HOAKS) STUDI ANALISIS WACANA KRITIS
}

\author{
Sukma Fatmawati, Rizky Salzabila, Galang Aulia Rizkitama, \\ Raden Arief Nugroho \\ sukmafw65@gmail.com \\ Universitas Dian Nuswantoro
}

\begin{abstract}
In the era of globalization, hoax news is increasingly rampant in social media and disrupts the joint harmony of Indonesian society. Not infrequently due to hoax news, Indonesian people are divided. The low level of public knowledge about identifying hoax news makes the reader influnced as if the news was genuine. This study aims to develop the "KAPAK HOAKS" model (Reader Independence to Analyze Content Hoax). This study uses the theory of Fairclough (1989). The research method used in this article is a qualitative method with a critical literature study approach. The research team collected theories of critical discourse analysis that can be used to analyze hoax data circulating on social media. Analysis is also done by matching the corpus of data with the selected theory. From the studies conducted, the authors succeeded in identifying the existence of linguistic aspects that could support increased self checking. This is also found in the arguments stated by Eriyanto (2001) about hoax news analysis. To make this research perfect, the authors consider it important that further research involves testing the response of social media readers to positive independence in responding to news hoaxes.
\end{abstract}

Keywords: hoax news, social media, semiotics, linguistics, corpus.

Berita hoaks saat ini yang marak terjadi dan tersebar di berbagai media. Baik itu media cetak maupun media online. Pada kemajuan teknologi informasi komunikasi saat ini tidak hanya memberikan dampak yang positif tetapi juga memberikan dampak buruk. Penyampaian berita maupun informasi begitu cepat dimana setiap orang dengan mudah memproduksi informasi. Mirisnya, masyarakat kurang peduli dengan adanya hal tersebut. Dengan mudahnya masyarakat mempercayai berita hoaks. Maraknya pengguna media internet membuat masyarakat dengan cepat mendapatkan informasi. Melalui beberapa media sosial seperti facebook, twitter, instagram ataupun 


\section{Sukma Fatmawati, Rizky Salzabila, Galang Aulia Rizkitama, Raden Arief}

Nugroho, Analisis Berita Hoaks di Korpus Sosial Media Guna Mengembangkan

Model "Kapak Hoaks" (Kemandirian Pembaca Menganalisis Konten Hoaks) Studi

Analisis Wacana Kritis

pesan telpon genggam seperti whatsapp, SMS dan lain sebagainya yang tidak dapat difilter dengan baik.

Informasi yang dikeluarkan oleh oknum-oknum yang tidak bertanggung jawab melalui media sosial ketika telah terkirim dan dibaca oleh banyak orang dapat memperngaruhi emosi, perasaan, pikiran bahkan tindakan seseorang atau kelompok. Sangat disayangkan apabila informasi apabila informasi yang disampaikan tersebut adlah informasi hoaks (bohong) dengan judul yang sangat provokatif mengirim pembaca dan penerima kepada opini yang negatif. Opini negatif, fitnah, penyebar kebencian yang diterima dan menyerang pihak ataupun membuat orang menjadi takut, terancam dan dapat merugikan pihak yang diberitakan sehingga dapat merusak reputasi dan menimbulkan kerugian materi.

CNN Indonesia menyebutkan bahwa dalam data yang dipaparkan oleh Kementerian Komunikasi dan Informatika menyebutkan ada sebanyak 800 ribu situs di Indonesia yang terindikasi sebagai penyebar berita palsu dan ujaran kebencian (hatespeech) (pratama,2006). Kemkominfo jufa selama tahun 2016 sudah memblokir 773 ribu situs berdasarkan pada 10 kelompok. Kesepuluh kelompok tersebut di antaranya mengandung unsur pornografi, SARA, Penipuan/dagang ilegal, Narkoba, Perjudian, Radikaslisme, Kekerasan, Keamanan Internet, dan Hak Kekayaan Intelektual (HKI). Dari jumlah itu, paling banyak yaitu unsur pornografi (Jamaludin,2016).

Walaupun pemerintah sudah giat mencangankan pemblokiran dan penghapusan situs situs media sosial yang berbau hoaks. Akan tetapi, setiap harinya akan selalu ada berita hoaks baru yang muncul dari media sosial yang di posting secara personal. Di Indonesia, tim peneliti mendapati sebuah alat yang digunakan untuk mengetahui berita hoaks tersebut, alat itu disebut sebagai Hoax Analyzer. Wujud dari alat tersebut, bisa bermacam-macam, seperti yang terdapat dalam laman www.hoaxanalyzer.com atau www.turnbackhoax.com. Namun, untuk mengembangkan alat tersebut, pengembang membutuhkan data yang konsisten dan besar, sehingga keberadaanya 
menjadi terbengkalai karena data hoaks itu berkembang setiap saat dan muncul dalam bentuk yang berbeda-beda. Hal itu menyebabkan kedua laman tersebut tidak dapat diakses lagi. Hal ini tentu saja menyebabkan penyebaran berita hoaks yang ada di Indonesia semakin tidak terkendali. Salah satu jalan terbaik yang bisa dilakukan dalam pemberantasan berita hoaks adalah melalui masyarakat pengguna media sosial sekaligus konsumen dari berita yang bertebaran di media sosial.

Sebagai masyarakat era milenial dan berpendidikan, kita harus pandai dalam menggali informasi. Kita harus cermat dalam membaca,meneliti dan menelusuri sumber dari berita tersebut. Hal penting yang harus kita lakukan adalah jangan terlalu mudah untuk menyebarluaskan berita tersebut sebelum berita tersebut diketahui keasliannya. Dilansir dari Kompas.com, beberapa faktor penyebab cepat beredarnya berita hoaks adalah: (1) masyarakat Indonesia sendiri yang dinilai tidak biasa berdemokrasi secara sehat; (2) kebanyakan masyarakat tidak terbiasa mencatat dan menyimpan data sehingga sering berbicara tanpa data; (3) Masyarakat Indonesia juga memiliki sifat dasar suka berincang, maka informasi yang diterima itu lalu dibagikan lagi tanpa melakukan verifikasi.

Mirisnya, banyak masyarakat Indonesia kini yang memiliki kemampuan menganalisis berita secara rendah. Hal tersebut menyebabkan banyak masyarakat yang menelan berita berita yang mereka dapatkan secara mentah mentah. Akibatnya, banyak terjadi pertikaian dan perpecahan ditengah masyarakat. Oleh sebab itu penting sekali adanya dorongan terhadap peningkatan kemandirian pembaca dalam menganalisis sebuah konten. Sebagai upaya untuk menganalisis berita hoaks secara mandiri tanpa bantuan alat atau software apapun (atau dengan kata lain mengembangkan self fact checking atau digital literacy), analisis wacana kritis dibutuhkan untuk menentukan karakteristik dan format berita hoaks. Jika seseorang yang awam dapat menganalisis sebuah berita dengan menggunakan parameter kebahasaan yang jelas, maka tanpa bantuan alat pun, ia dapat mengetahui apakah berita itu bohong atau asli. Untuk menganalisis berita hoaks dengan menggunakan analisis wacana kritis, maka ada beberapa cara yang bisa dilakukan (Eriyanto,2001) seperti: Pemilihan kosata, presuposisi, penggambaran peristiwa dan penggambaran 


\section{Sukma Fatmawati, Rizky Salzabila, Galang Aulia Rizkitama, Raden Arief} Nugroho, Analisis Berita Hoaks di Korpus Sosial Media Guna Mengembangkan Model "Kapak Hoaks" (Kemandirian Pembaca Menganalisis Konten Hoaks) Studi Analisis Wacana Kritis

orang/kelompok. Analisis tersebut terdiri dari dua jenis analisis, yaitu linguistik dan semiotik. Pemilihan kata dan presuposisi adalah aspek linguistik yang dianalisis dalam sebuah analisis wacana kritis, sedangkan penggambaran peristiwa dan orang melalui gambar atau tipologi huruf merupakan jenis dari analisis semiotik.

\section{LANDASAN TEORI}

\section{Hoaks}

Hoaks adalah kabar, informasi, berita bohong atau palsu. Dalam KBBI hoaks berarti berita bohong. Sedangkan menurut cambridge dictionary, kata hoaks berarti tipuan atau lelucon. Kegiatan menipu, rencana menipu, trik menipu, disebut dengan hoaks. Berdasarkan situs hoaxes.org, dalam konteks budaya, hoaks diartikan sebagai aktifitas menipu. Menurut Dewan Pers, ciri-ciri hoax terdiri dari pertama mengakibatkan kecemasan, kebencian dan permusuhan. Kedua adalah sumber berita tidak jelas. Hoax media sosial biasanya pemberitaan media yang tidak terverifikasi, tidak berimbang dan cenderung nenyudutkan pihak tertentu. Sementara yang ketiga adalah bermuatan fanatisme atas nama ideologi, judul dan pengantarnya provokatif, memberikan penghukuman serta menyembuyikan fakta dan data. Sedangkan menurut Romeltea (2017) ciri utama hoax adalah tanpa sumber. Penyebar hoax biasanya menuliskan: ‘copas dari grup sebelah' atau 'kiriman teman'.

Di Indonesia, hoaks banyak terjadi sejak terselenggaranya Pilpres 2014 sebagai platform kampanye yang gencar di media sosial. Dalam jagad dunia maya, banyak berita sampah, euforia, dan tipuan yang digunakan sebagai ajang saling menuding dan saling fitnah tanpa dilengkapi dengan adanya fakta. Lebih dari itu, berita berita yang ada di media sosial akan mudah disebar atau di re-upload atau diteruskan oleh pengguna sosial media.

Dengan banyaknya berita hoax yang tersebar di media sosial, mengharuskan masyarakat untuk lebih teliti dan tidak mudah percaya begitu saja dengan apa yang 
mereka baca, terlebih lagi dengan sumber yang belum jelas. Selain masyarakat yang menjadi korbannya, media pemberitaan online yang memang menyajikan berita yang faktual dan aktual juga menjadi sasaran ketidakpercayaan masyarakat terhadap berita online. Untuk itu, dalam menerima dan menyebarkan berita di media sosial terkhususnya Facebook, masyarakat harus bisa memilahmilih dan mencari tahu kebenaran berita tersebut tidak dari satu sumber dan jangan mudah untuk menyebarkan suatu berita yang belum tentu kebenarannya hanya karena berita tersebut sangat meyakinkan.

\section{Media Sosial}

Media sosial merupakan salah satu platform yang muncul di media siber. Karena itu, melihat media sosial yang tidak jauh berbeda dengan karakteristik yang dimiliki oleh media siber. Namun, ada batasan-batasan dan ciri khusus tertentu yang hanya dimiliki oleh media sosial dibanding dengan media lainnya. Pada akhirnya, bagaimana karakteristik media sosial itu bisa dipergunakan untuk bidang seperti jurnalisme, hubungan masyarakat, pemasaran, politik. Nasrullah (2015: 16) mengemukakan ada 6 karakteristik media sosial, yaitu: Jaringan (netwok); Informasi (information); Arsip (archive); Interaksi (interactivity); Simulasi sosial (simulation of society); Konten oleh pengguna (user-generated content).

Menurut Kaplan dan Haenlein (2010) ada enam jenis media sosial sebagai berikut : (1) Proyek Kolaborasi adalah website mengizinkan usernya untuk dapat mengubah, menambah, ataupun me-remove konten konten yang ada di website. (2) Blog dan Microblog User lebih bebas dalam mengekspresikan sesuatu di blog ini seperti curhat ataupun mengkritik kebijakan pemerintah. Contohnya twitter. (3) Konten adalah para user dari pengguna website ini saling meng-share konten-konten media, baik seperti video, e-book, dan gambar. Contohnya Youtube. (4) Situs Jejaring Sosial adalah Aplikasi yang mengizinkan user untuk dapat terhubung dengan cara membuat informasi pribadi sehingga dapat terhubung dengan orang lain. Informasi pribadi itu bisa seperti foto-foto. Contohnya Facebook. (5) Virtual Game World adalah dunia virtual, di mana mengreplikasikan lingkunagn 3D, di mana user bisa muncul dalam bentuk avatar-avatar yang diinginkan serta berinteraksi dengan orang 


\section{Sukma Fatmawati, Rizky Salzabila, Galang Aulia Rizkitama, Raden Arief} Nugroho, Analisis Berita Hoaks di Korpus Sosial Media Guna Mengembangkan Model "Kapak Hoaks" (Kemandirian Pembaca Menganalisis Konten Hoaks) Studi Analisis Wacana Kritis

lain selayaknya di dunia nyata. Contohnya game online. (6) Virtual Social World adalah dunia virtual yang penggunanya merasa hidup di dunia virtual, sama seperti virtual game world, berinteraksi dengan yang lain. Namun, virtual social world lebih bebas, dan lebih ke arah kehidupan. Contohnya second life.

\section{Teori Critical Discourse Analysis}

Normal Fairclough (1989) mengemukakan analisis wacana yang menggambarkan mengenai hubungan antara teks dengan lingkungan sosialnya.

\begin{tabular}{|ll|}
\hline Unsur & Wacana yang ingin dilihat \\
& Bagaimana peristiwa, orang, kelompok, \\
& situasi, keadaan, atau apapun ditampilkan \\
& dan digambarkan dalam teks. \\
\hline Relasi & Bagaimana hubungan antara wartawan, \\
khalayak, dan partisipan berita ditampilkan \\
dan digambarkan dalam teks.
\end{tabular}

Tabel 1. Model analisis yang dikembangkan oleh Normal Fairclough

Menurut Fairclough, (dalam Eriyanto, 2001) Teks adalah kata atau kalimat yang menggambarkan obyek pemberitaan, sekaligus menjelaskan hubungan-hubungan antar obyek yang didefinisikan. Discourse Practice dipahami sebagain bentuk teks yang dibentuk lewat suatu praktik diskursus yang akan menentukan bagaimana teks tersebut diproduksi. Bagian ini membahas lebih khusus tentang bagaimana teks diproduksi dan dikonsumsi. Sedangkan Sociocultural Practice dijabarkan sebagai sebuah konteks yang tidak bersentuhan langsung dengan teks media, tetapi suatu konteks yang ada di luar media namun mempengaruhi bagaimana wacana yang muncul di media. 
Teks dalam media massa, termasuk website penyedia konten hoaks, berhubungan dengan linguistik atau tata bahasa. Ada pemilihan kosakata, semantik, hingga struktur kalimat yang harus dilihat, termasuk koherensi dan kohesifitasnya. Dalam analisis teks ini, Fairclough masih membaginya menjadi tiga hal, ideasional atau representasi, relasi, dan identitas.

\section{METODE PENELITIAN}

Penelitian ini menggunakan pendekatan kualitatif dengan metode deskriptif guna mendapatkan ciri-ciri dari berita hoaks tersebut. Tim peneliti menggunakan teori Kaplan dan Haenlein (2010) untuk menentukan jenis media sosial yang digunakan untuk penyebaran berita haoks. Kategori jenis media sosial yang kami gunakan untuk penelitian ini adalah website, blog, konten, jejaring Sosial, virtual game world. Tim peneliti juga menggunakan teori critical discourse analysis dari Norman Fairlough(1989) untuk menentukan ciri-ciri berita hoaks mengacu pada unsur representasi, relasi, identitas. Hasil penelitian ini akan kami jadikan sebagai bahan untuk pembuatan Korpus Sosial Media Guna Mengembangkan Model "KAPAK HOAKS" (Kemandirian Pembaca Menganalisis Konten Hoaks) Studi Analisis Wacana Kritis).

\section{HASIL DAN PEMBAHASAN}

Berdasarkan analisis data, tim peneliti mengumpulkan 40 sampel data berita hoaks yang tersebar di berbagai media sosial dalam kurun waktu 2 tahun (2017-2018) sebagai berikut :

\begin{tabular}{|c|l|l|l|l|}
\hline No & Tanggal & \multicolumn{1}{|c|}{ Media } & \multicolumn{1}{|c|}{ Judul } & \multicolumn{1}{|c|}{ Kategori } \\
\hline 1 & $\begin{array}{l}28 \\
\text { September } \\
2018\end{array}$ & Suarabmi.com & $\begin{array}{l}\text { Peneliti asing prediksi Indonesia } \\
\text { bisa dilanda gempa maha } \\
\text { dahsyat 9,5 SR }\end{array}$ & Sosial \\
\hline 2 & $\begin{array}{l}18 \\
\text { Desember } \\
2017\end{array}$ & $\begin{array}{l}\text { FB Mak Lambe } \\
\text { Turah }\end{array}$ & $\begin{array}{l}\text { PDIP tak butuh suara umat } \\
\text { islam }\end{array}$ & Politik \\
\hline
\end{tabular}


Sukma Fatmawati, Rizky Salzabila, Galang Aulia Rizkitama, Raden Arief Nugroho, Analisis Berita Hoaks di Korpus Sosial Media Guna Mengembangkan Model "Kapak Hoaks" (Kemandirian Pembaca Menganalisis Konten Hoaks) Studi Analisis Wacana Kritis

\begin{tabular}{|c|c|c|c|c|}
\hline 3 & $\begin{array}{l}4 \text { Januari } \\
2017\end{array}$ & Broadcast WA & Waspada Dokter Kandungan & Kesehatan \\
\hline 4 & $\begin{array}{l}8 \\
\text { Desember } \\
2018\end{array}$ & $\begin{array}{l}\text { FB Supri Yadi } \\
\text { Ibn Almahdi }\end{array}$ & Bom Meledak saat reuni 212 & Sosial \\
\hline 5 & $\begin{array}{l}7 \\
\text { Desember } \\
2018\end{array}$ & $\begin{array}{l}\text { FB Doni } \\
\text { Ramadhan }\end{array}$ & $\begin{array}{l}\text { JK dukung Prabowo selamatkan } \\
\text { diri dari partai PKI }\end{array}$ & Politik \\
\hline 6 & $\begin{array}{l}11 \\
\text { Desember } \\
2018\end{array}$ & $\begin{array}{l}\text { FB Kakek } \\
\text { Detektif }\end{array}$ & $\begin{array}{l}\text { Prabowo Subianto berpakaian } \\
\text { pendeta }\end{array}$ & Sosial \\
\hline 7 & $\begin{array}{l}13 \\
\text { Desember } \\
2018\end{array}$ & $\begin{array}{l}\text { FB Chandra } \\
\text { Irawan }\end{array}$ & $\begin{array}{l}\text { Huan Chin lolos dari hukuman } \\
\text { mati karena ia China }\end{array}$ & Internasional \\
\hline 8 & $\begin{array}{l}19 \\
\text { Desember } \\
2018\end{array}$ & FB Anisa Banraji & $\begin{array}{l}500 \text { ribu tentara China akan } \\
\text { menghanguskan Indonesia }\end{array}$ & Sosial \\
\hline 9 & $\begin{array}{l}18 \\
\text { Desember } \\
2018\end{array}$ & $\begin{array}{l}\text { FB CutAisya } \\
\text { Nursiah } \\
\text { Abubakar }\end{array}$ & $\begin{array}{l}\text { Cina akan menyerang Indonesia } \\
\text { jika ikut campur soal muslim } \\
\text { uighur }\end{array}$ & Sosial \\
\hline 10 & $\begin{array}{l}28 \\
\text { Desember } \\
2018\end{array}$ & $\begin{array}{l}\text { FB Sep Zm } \\
\text { Santri Pelajar }\end{array}$ & $\begin{array}{l}\text { Jokowi meresmikan patung } \\
\text { yesus }\end{array}$ & Sosial \\
\hline 11 & $\begin{array}{l}25 \\
\text { Desember } \\
2018\end{array}$ & $\begin{array}{l}\text { FB Gerakan } 2019 \\
\text { Ganti Presiden }\end{array}$ & $\begin{array}{l}\text { KPU kumpulkan pendatang } \\
\text { China untuk memenangkan } \\
\text { Jokowi }\end{array}$ & Politik \\
\hline 12 & & Broadcast WA & Whatsapp dikenai biaya & Sosial \\
\hline 13 & & Broadcast WA & $\begin{array}{l}\text { Cabe bubuk penuh kencing } \\
\text { tikus }\end{array}$ & Kesehatan \\
\hline
\end{tabular}


121 LกึTE, Volume 15 Nomor 2, September 2019

\begin{tabular}{|c|c|c|c|c|}
\hline 14 & & Broadcast WA & $\begin{array}{l}\text { Memberitahukan berita } 1 \text { Rajab } \\
\text { maka haram neraka baginya }\end{array}$ & Religi \\
\hline 15 & $\begin{array}{l}1 \\
\text { Desember } \\
2018\end{array}$ & Wapresri.go.id & $\begin{array}{l}\text { Komitmen Indonesia tangani } \\
\text { perubahan iklim dan } \\
\text { pembangunan perkelanjutan }\end{array}$ & Sosial \\
\hline 16 & & Broadcast WA & $\begin{array}{l}\text { Anak menangis di jalan adalah } \\
\text { penjahat }\end{array}$ & Sosial \\
\hline 17 & & Broadcast WA & $\begin{array}{l}\text { Hacker sudah mulai memasuki } \\
\text { WA }\end{array}$ & Lifestyle \\
\hline 18 & & $\begin{array}{l}\text { Intagram } \\
\text { rakyat_bersatu }\end{array}$ & $\begin{array}{l}\text { Tanggapan walikota bandung } \\
\text { terhadap vonis Ahok }\end{array}$ & Sosial \\
\hline 19 & & $\begin{array}{l}\text { Instagram } \\
\text { fadjroelrachman }\end{array}$ & $\begin{array}{l}180 \text { bis diberangkatkan serentak } \\
\text { oleh presiden jokowidodo }\end{array}$ & Sosial \\
\hline 20 & & $\begin{array}{l}\text { Instagram } \\
\text { augiefantinus }\end{array}$ & polisi menjadi oknum calo & Sosial \\
\hline 21 & & $\begin{array}{l}\text { Instagram } \\
\text { reaksirakyat1 }\end{array}$ & Ridwan kamil dukung LGBT & Sosial \\
\hline 22 & $\begin{array}{l}5 \text { Februari } \\
2010\end{array}$ & Kompas.com & $\begin{array}{l}\text { Sepasang naga gemparkan } \\
\text { warga kutai barat }\end{array}$ & Sosial \\
\hline 23 & $\begin{array}{l}12 \\
\text { Desember } \\
2018\end{array}$ & Kaskusinfo & $\begin{array}{l}\text { Jokowi tidak pernah menaikkan } \\
\text { harga BBM, yang menaikan ya } \\
\text { pertamina }\end{array}$ & Ekonomi \\
\hline 24 & $\begin{array}{l}27 \quad \text { Maret } \\
2019\end{array}$ & FB Revy Sukma & $\begin{array}{l}\text { Presiden Turki Recep Tayyip } \\
\text { Erdogan telah memberikan } \\
\text { dukungan kepada Prabowo- } \\
\text { Sandi }\end{array}$ & Politik \\
\hline 25 & $\begin{array}{l}23 \text { Maret } \\
2019\end{array}$ & FB Mayang Sari & $\begin{array}{l}\text { PDIP tidak membutuhkan } \\
\text { dukungan dan suara umat } \\
\text { Islam }\end{array}$ & Politik \\
\hline 26 & & WhatsApp grup & Mencuci dan mengeringkan biji & Sosial \\
\hline
\end{tabular}


Sukma Fatmawati, Rizky Salzabila, Galang Aulia Rizkitama, Raden Arief Nugroho, Analisis Berita Hoaks di Korpus Sosial Media Guna Mengembangkan Model "Kapak Hoaks" (Kemandirian Pembaca Menganalisis Konten Hoaks) Studi Analisis Wacana Kritis

\begin{tabular}{|c|c|c|c|c|}
\hline & & & $\begin{array}{l}\text { buah-buahan serta menanamnya } \\
\text { dapat tumbuh di musim hujan, } \\
\text { seperti yang dilakukan di } \\
\text { Thailand }\end{array}$ & \\
\hline 27 & $\begin{array}{l}8 \quad \text { Juni } \\
2018 .\end{array}$ & $\begin{array}{l}\text { FB Mursyidi pake } \\
\text { Ie }\end{array}$ & $\begin{array}{l}\text { Seorang Syekh Palestina } \\
\text { Tidak Mempan Ditembak } \\
\text { Zionis Israel }\end{array}$ & Religi \\
\hline 28 & $\begin{array}{l}24 \text { Maret } \\
2019\end{array}$ & Tribun.pos & $\begin{array}{l}\text { Mendagri Melarang Kades dan } \\
\text { Lurah Bersikap Netral }\end{array}$ & Politik \\
\hline 29 & $\begin{array}{l}25 \quad \text { Maret } \\
2019\end{array}$ & $\begin{array}{l}\text { Tribun Politik } \\
\text { Ade Armando }\end{array}$ & $\begin{array}{l}\text { Prabowo Subianto } \\
\text { Merendahkan Kaum Miskin } \\
\text { Indonesia di Forum Dunia }\end{array}$ & Politik \\
\hline 30 & $\begin{array}{ll}18 & \text { Feb } \\
2019 & \end{array}$ & $\begin{array}{l}\text { Teropongsenaya } \\
\text { n.com }\end{array}$ & $\begin{array}{l}\text { Polisi Menetapkan Jokowi } \\
\text { Tersangka Penyebar Hoaks }\end{array}$ & Sosial \\
\hline 31 & $\begin{array}{l}9 \quad \text { Maret } \\
2019\end{array}$ & $\begin{array}{l}\text { FB Jainudin } \\
\text { Ngacir }\end{array}$ & $\begin{array}{l}\text { Penggunaan Kotak Suara } \\
\text { Berbahan Kardus Sengaja } \\
\text { Dirancang Agar Mudah } \\
\text { Ditukar }\end{array}$ & Politik \\
\hline 32 & $\begin{array}{l}14 \quad \text { Maret } \\
2019\end{array}$ & FB Nil Masni & $\begin{array}{l}\text { Pemerintah Sudah Setujui } \\
\text { Nominal Tunjangan untuk } \\
\text { Pengangguran }\end{array}$ & Sosial \\
\hline 33 & $\begin{array}{l}11 \text { Maret } \\
2019\end{array}$ & $\begin{array}{l}\text { FB Ahmadi } \\
\text { Brenk }\end{array}$ & $\begin{array}{l}\text { Warga Wawonii Mengamuk } \\
\text { Karena Tanah Leluhurnya } \\
\text { Diserobot Investor Asing. }\end{array}$ & Sosial \\
\hline 34 & $\begin{array}{l}20 \\
\text { Februari } \\
2017\end{array}$ & Radiomuara.com & $\begin{array}{l}\text { Selebritis Agnes Monica yang } \\
\text { pindah agama }\end{array}$ & Selebriti \\
\hline 35 & $\begin{array}{l}3 \text { Januari } \\
2019\end{array}$ & $\begin{array}{l}\text { FB Rhodi } \\
\text { Casmadi }\end{array}$ & $\begin{array}{l}\text { Menteri Agama Larang } \\
\text { Penggunaan Toa untuk Adzan }\end{array}$ & Religi \\
\hline
\end{tabular}


Lก๊ TEE, Volume 15 Nomor 2, September 2019

\begin{tabular}{|c|c|c|c|c|}
\hline & & & dan Ceramah & \\
\hline 36 & $\begin{array}{l}3 \text { Januari } \\
2018\end{array}$ & $\begin{array}{l}\text { FB Laras Dwi } \\
\text { Paramitha }\end{array}$ & $\begin{array}{l}\text { Megawati Minta Jokowi Pecat } \\
\text { TNI Perazia Buku Komunisme }\end{array}$ & Politik \\
\hline 37 & $\begin{array}{l}5 \text { Januari } \\
2019\end{array}$ & $\begin{array}{l}\text { FB Ulin Niam } \\
\text { Yusron }\end{array}$ & Prabowo Bisa Ngaji & Religi \\
\hline 38 & $\begin{array}{l}28 \\
\text { Desember } \\
2018\end{array}$ & FB Tata & $\begin{array}{l}\text { Penasihat Istana RI adalah } \\
\text { Anggota Partai Komunis Cina }\end{array}$ & Sosial \\
\hline 39 & $\begin{array}{l}14 \text { Januari } \\
2018\end{array}$ & TEMPO.CO & $\begin{array}{l}\text { Banyak Kasus Bunuh Diri di } \\
\text { Indonesia Seperti Pidato } \\
\text { Prabowo }\end{array}$ & Sosial \\
\hline 40 & $\begin{array}{l}17 \text { Januari } \\
2018\end{array}$ & $\begin{array}{l}\text { FB Dian Putri } \\
\text { Maunk }\end{array}$ & $\begin{array}{l}\text { Mentos edisi I Love Israel } \\
\text { beredar di Indonesia }\end{array}$ & Sosial \\
\hline
\end{tabular}

Tabel 2. Daftar berita hoaks yang tersebar di media sosial

Berdasarkan data tersebut dapat diambil kesimpulan presentase sebagai berikut :

\begin{tabular}{|l|c|}
\hline \multicolumn{1}{|c|}{ Jenis Berita } & Persentase \\
\hline Berita sosial & $52,5 \%$ \\
\hline Berita politik & $22,5 \%$ \\
\hline Beriya religi & $10 \%$ \\
\hline Berita kesehatan & $5 \%$ \\
\hline Berita lifestyle & $2,5 \%$ \\
\hline Berita ekonomi & $2,5 \%$ \\
\hline Berita selebritis & $2,5 \%$ \\
\hline Berita internasional & $2,5 \%$ \\
\hline Jumlah & $100 \%$ \\
\hline
\end{tabular}

Tabel 3. Persentase jenis berita hoaks 
Sukma Fatmawati, Rizky Salzabila, Galang Aulia Rizkitama, Raden Arief Nugroho, Analisis Berita Hoaks di Korpus Sosial Media Guna Mengembangkan Model "Kapak Hoaks" (Kemandirian Pembaca Menganalisis Konten Hoaks) Studi Analisis Wacana Kritis

\begin{tabular}{|l|c|}
\hline Jenis media sosial & Persentase \\
\hline Jejaring social & $77,5 \%$ \\
\hline Blog & $12,5 \%$ \\
\hline Website & $10 \%$ \\
\hline Konten & $0 \%$ \\
\hline Virtual game world & $0 \%$ \\
\hline Jumlah & $100 \%$ \\
\hline
\end{tabular}

Tabel 4. Persentase jenis media sosial

\begin{tabular}{|l|c|}
\hline \multicolumn{1}{|c|}{ Ciri ciri berita hoaks } & Persentase \\
\hline Bahasa tidak baku & $20 \%$ \\
\hline $\begin{array}{l}\text { Penggunaan huruf kapital } \\
\text { tidak tepat }\end{array}$ & $15 \%$ \\
\hline $\begin{array}{l}\text { Terdapat tanda untuk } \\
\text { memfokuskan gambar }\end{array}$ & $12,5 \%$ \\
\hline $\begin{array}{l}\text { Tidak ada identitas } \\
\text { narasumber }\end{array}$ & $10 \%$ \\
\hline $\begin{array}{l}\text { Tidak ada identitas } \\
\text { wartawan }\end{array}$ & $10 \%$ \\
\hline $\begin{array}{l}\text { Tidak ada gambar } \\
\text { pendukung berita }\end{array}$ & $8,5 \%$ \\
\hline $\begin{array}{l}\text { Tidak ada wawancara } \\
\text { narasumber }\end{array}$ & $3,5 \%$ \\
\hline Waktu kejadian tidak jelas & $3 \%$ \\
\hline $\begin{array}{l}\text { Penulisan berita tidak } \\
\text { melihat konteks }\end{array}$ & \\
\hline Antara gambar dan isi berita & \\
\hline
\end{tabular}




\begin{tabular}{|l|c|}
\hline tidak saling berhubungan & \\
\hline Jumlah & $100 \%$ \\
\hline
\end{tabular}

Tabel 5. Persentase ciri ciri berita hoaks

Berdasarkan 40 data yang didapat di media sosial persentasi berita sosial sebesar $52,5 \%$, berita politik sebesar $22,5 \%$, berita lifestyle sebesar $2,5 \%$, berita religi sebesar $10 \%$, berita ekonomi $2,5 \%$, berita kesehatan $5 \%$, berita selebritis $2,5 \%$, dan berita internasional $2,5 \%$. Sedangkan media sosial yang digunakan sebagai sarana hoaks dari jejaring sosial sebesar 77,5\%, dari website sebesar $12,5 \%$, blog sebesar $10 \%$, konten sebesar $0 \%$, dan dari virtual game world sebesar $0 \%$.

Persentase ciri ciri berita hoaks yang terdapat dalam 40 data tersebut dari bahasa tidak baku sebesar $20 \%$, penggunaan huruf kapital tidak tepat sebesar $15 \%$, terdapat tanda untuk memfokuskan gambar sebesar $12,5 \%$, tidak ada identitas narasumber sebesar $10,5 \%$, tidak ada identitas wartawan sebesar $10 \%$, tidak ada gambar pendukung berita sebesar $10 \%$, tidak ada wawancara narasumber sebesar 8,5 \%, waktu kejadian tidak jelas sebesar 7,5 \%, penulisan berita tidak melihat konteks sebesar $3 \%$, dan antara gambar dan isi berita tidak saling berhubungan sebesar $3 \%$.

\section{Analisis data berdasarkan jenis media sosial dan critical discourse analysis :}

\section{Data (1) Akun Facebook Jainudin Ngacir. 9 Maret 2019.}

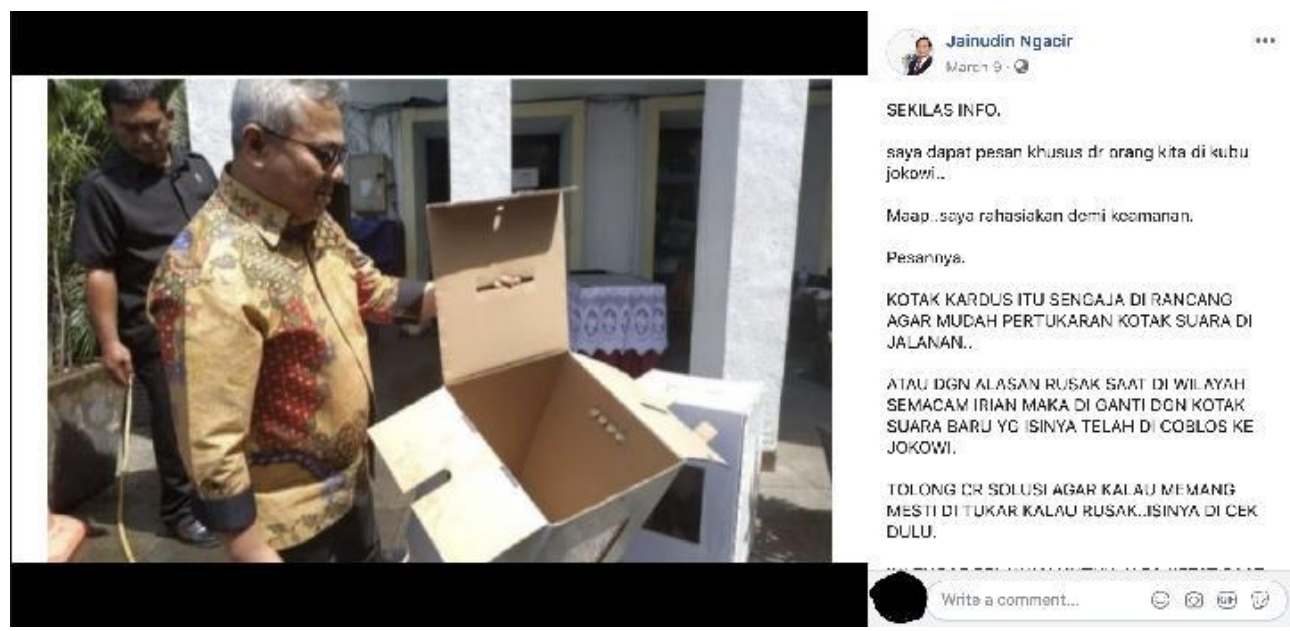




\section{Sukma Fatmawati, Rizky Salzabila, Galang Aulia Rizkitama, Raden Arief}

Nugroho, Analisis Berita Hoaks di Korpus Sosial Media Guna Mengembangkan Model "Kapak Hoaks" (Kemandirian Pembaca Menganalisis Konten Hoaks) Studi Analisis Wacana Kritis

Dari data di atas, jenis media sosial media yang digunakan untuk menyebarkan berita hoax adalah melalui jejaring sosial facebook. Unsur representasi yang terjadi didalam berita tersebut adalah penulis menambilkan sebuah gambar seseorang yang sedang memegang kardus kotak suara serta memberikan caption dengan bahasa yang tidak baku dan penggunaan huruf kapital yang tidak konsisten. Di dalam berita tersebut tidak tertulis kapan, dimana, bagaiana, dan dengan siapa kejadian tersebut berlangsung, sehingga tidak memenuhi syarat penulisan sebuah berita. Penulis juga tidak memberikan tambahan sumber manapun sebagai pendukung fakta dari tulisan yang telah ia buat. Unsur relasi yang terjadi adalah tidak adanya wawancara yang dilakukan oleh penulis terhadap narasumber isi berita, sehingga tidak dapat mendukung fakta yang telah tertulis di dalam berita. Unsur identitas yang ada di dalam berita tersebut yaitu tidak dicantumkannya identitas dari narasumber dan wartawan, hanya terdapat identitas dari akun jejaring sosial yang digunakan untuk membagikan berita tersebut.

\section{Data (2) Broadcast Whatsapp}

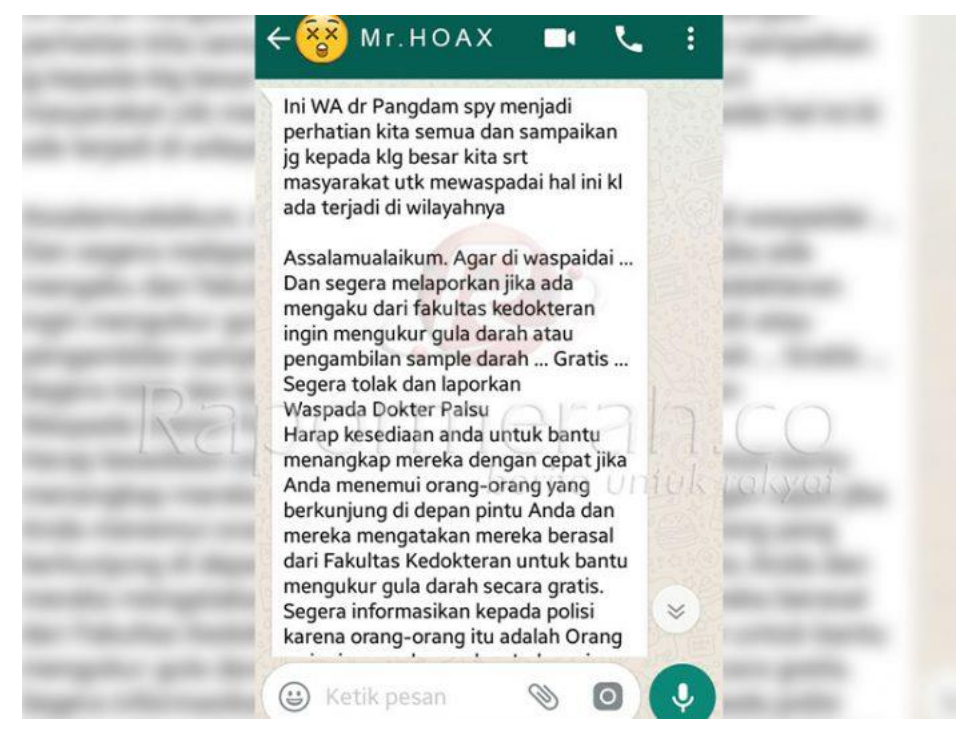

Dari data di atas, jenis media sosial media yang digunakan untuk menyebarkan berita hoax adalah melalui jejaring sosial WhatsApp. Unsur representasi yang terjadi didalam berita tersebut adalah penulis tidak memberikan tambahan gambar untuk 
mendukung fakta berita. Di dalam berita tersebut tidak tertulis kapan, di mana, bagaiana, dan dengan siapa kejadian tersebut berlangsung secara lengkap. Penulisan berita juga tidak menggunakan format penulisan berita yang baku serta banyak tulisan yang disingkat singkat. Penulis juga tidak memberikan tambahan sumber berita manapun sebagai pendukung fakta dari tulisan yang telah ia buat. Unsur relasi yang terjadi adalah tidak adanya wawancara yang dilakukan oleh penulis terhadap narasumber isi berita, sehingga tidak dapat mendukung fakta yang telah tertulis di dalam berita. Unsur identitas yang ada di dalam berita tersebut yaitu tidak dicantumkannya identitas dari narasumber dan wartawan. Identitas penulis berita sangat sulit ditemukan karena berita tersebut dapat dengan mudah di share dari satu orang ke orang lainnya dalam jejaring sosial tersebut.

Data (3) Website suarabmi.com. 28 September 2018.

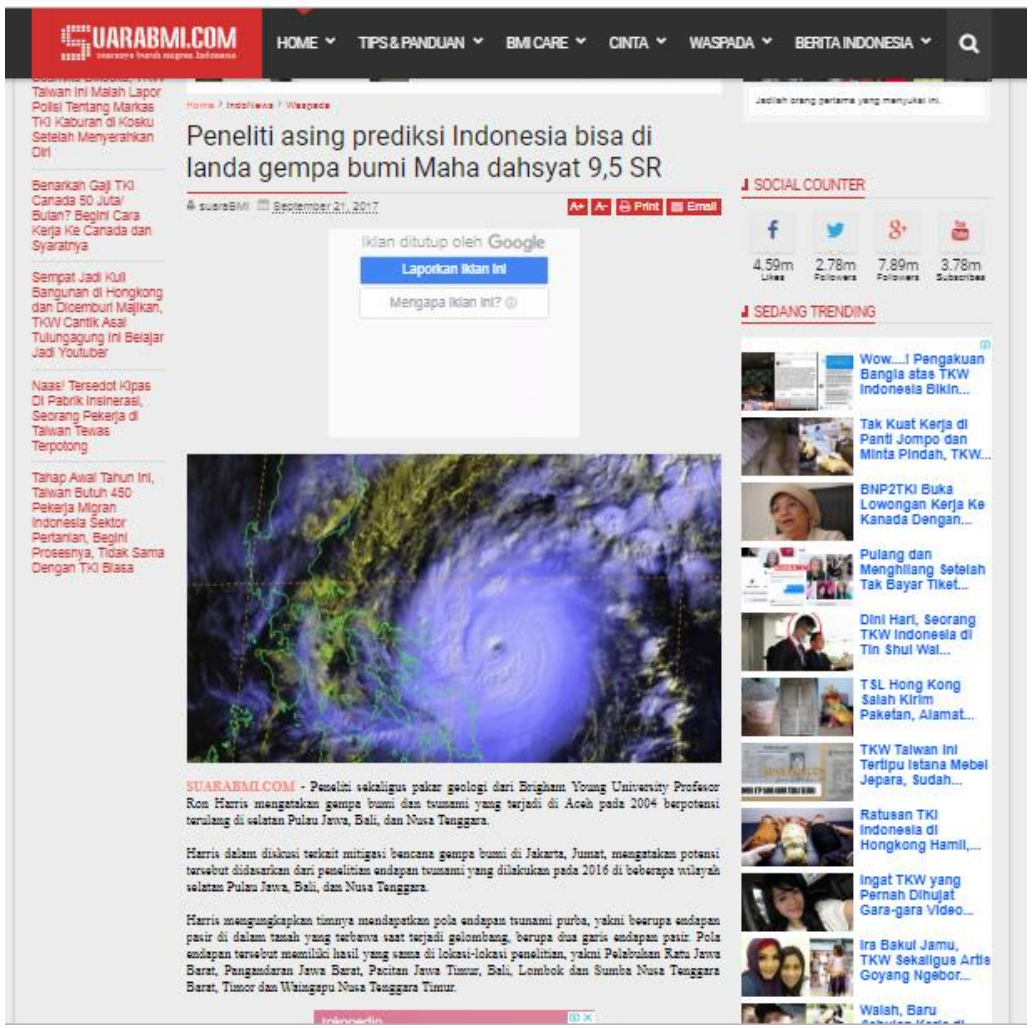

Dari data di atas, jenis media sosial media yang digunakan untuk menyebarkan berita hoax adalah melalui website. Unsur representasi yang terjadi didalam berita tersebut adalah penulis sudah memberikan tambahan gambar untuk mendukung fakta 


\section{Sukma Fatmawati, Rizky Salzabila, Galang Aulia Rizkitama, Raden Arief}

Nugroho, Analisis Berita Hoaks di Korpus Sosial Media Guna Mengembangkan Model "Kapak Hoaks" (Kemandirian Pembaca Menganalisis Konten Hoaks) Studi Analisis Wacana Kritis

yang ada di dalam berita. Penulis sudah menulis berita yang sesuai dengan format $5 \mathrm{~W}+1 \mathrm{H}$. Akan tetapi, dalam penulisan judul penulis tidak menggunakan struktur tulisan yang baku. Penulis juga tidak melihat konteks yang ada di dalam berita. Sehingga, berdarkan sumber berita, berita tersebut menggunakan fakta atau data yang benar. Namun, cara penyampaian atau kesimpulannya keliru, sehingga mengarah kepada tafsir berita yang salah. Unsur relasi yang terjadi adalah ada wawancara yang dikutip dalam berita tersbut, tetapi menulis tidak memahami konteks yang ada di dalam wawancara tersebut. Unsur identitas yang ada di dalam berita tersebut yaitu penulis mencantumkan identitas narasumber, tetapi identitas penulis berita tidak tercantum.

\section{Data (4) Instagram rakyat_bersatu}

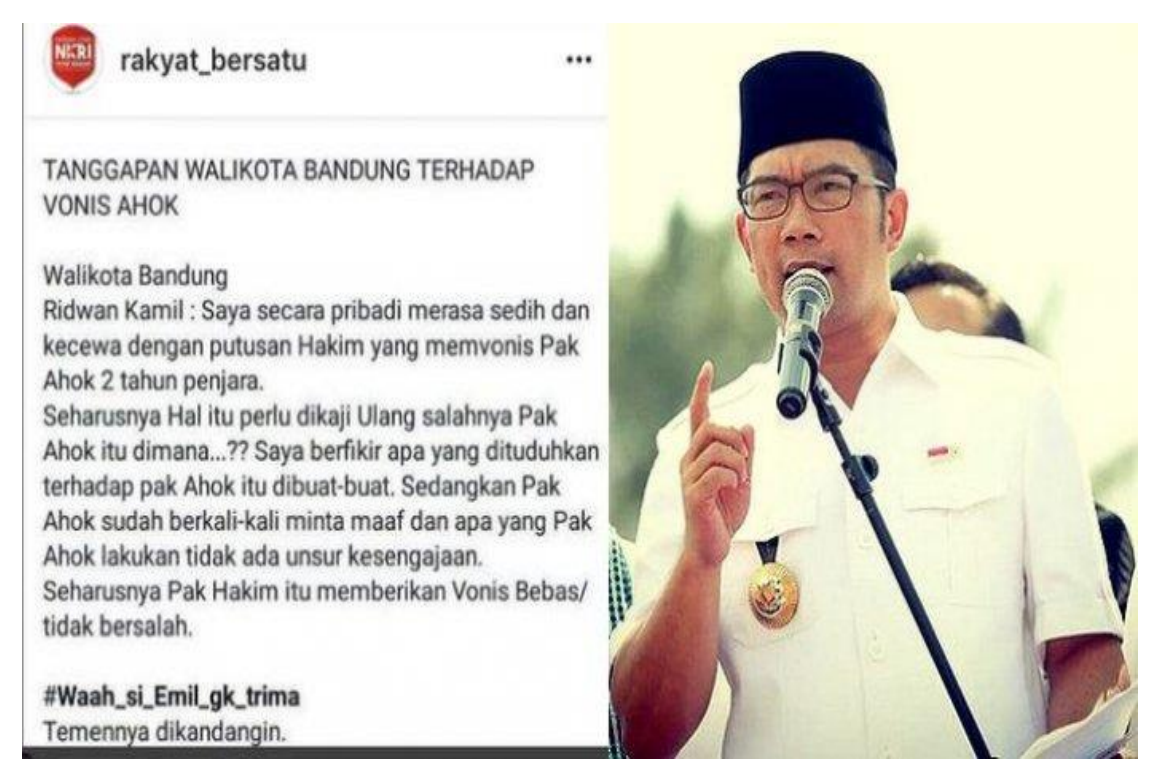

Dari data di atas, jenis media sosial media yang digunakan untuk menyebarkan berita hoax adalah melalui jejaring sosial berupa instagram. Unsur representasi yang terjadi didalam berita tersebut adalah penulis sudah memberikan tambahan gambar untuk mendukung isi berita, namun gambar yang disertakan tidak diambil pada saat narasumber mengeluarkan opini yang sesungguhnya. Bahasa yang digunakan penulis cenderung tidak baku dan menyudutkan satu pihak tertentu saja tanpa melihat dari 
pihak lainnya. Unsur relasi yang terjadi adalah berita cenderung menyudutkan dan kutipan narasumber tidak disertai dengan waktu dan tempat opini diutarakan. Unsur identitas yang ada di dalam berita tersebut yaitu berita tersebut menyantumkan identitas narasumber, tetapi identitas penulis berita tidak tercantum.

\section{Data (5) Postingan Ulhy dalam akun facebook Gerakan 2019 Ganti President}

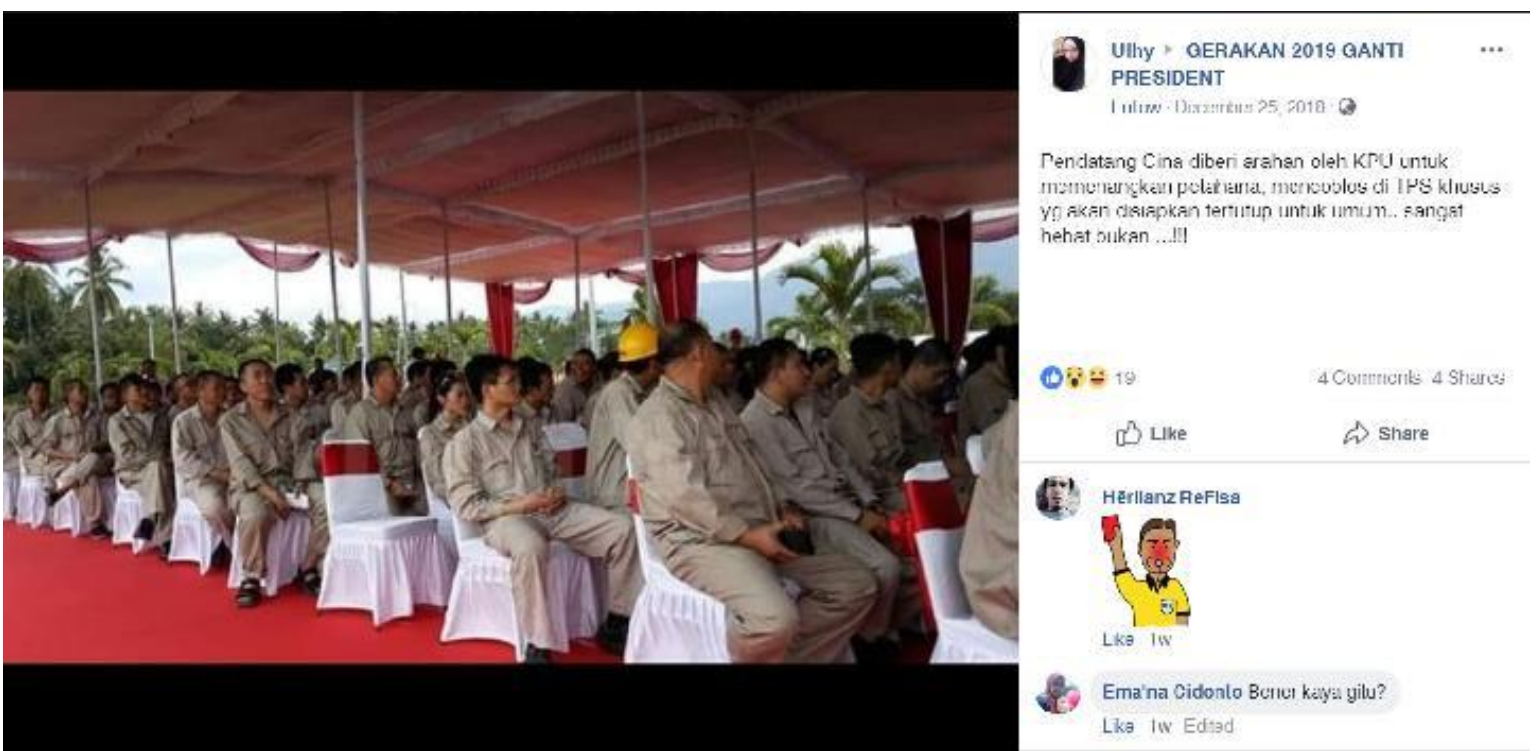

Dari data di atas, jenis media sosial media yang digunakan untuk menyebarkan berita hoax adalah melalui jejaring sosial facebook. Unsur representasi yang terjadi didalam berita tersebut adalah penulis menambilkan sebuah sekelompok etnis china sedang duduk menunggu sesuatu. Akan tetapi, kejadian digambar tersebut tidak sesuai dengan isi berita yang ditulis. Di dalam berita tersebut juga tidak tertulis kapan, dimana, bagaimana, dan dengan siapa kejadian tersebut berlangsung, sehingga tidak memenuhi syarat penulisan sebuah berita. Penulis juga tidak memberikan tambahan sumber manapun sebagai pendukung fakta dari tulisan yang telah ia buat. Unsur relasi yang terjadi adalah tidak adanya wawancara yang dilakukan oleh penulis terhadap narasumber isi berita, sehingga tidak dapat mendukung fakta yang telah tertulis di dalam berita. Unsur identitas yang ada di dalam berita tersebut yaitu tidak dicantumkannya identitas dari narasumber dan wartawan, hanya terdapat identitas dari akun jejaring sosial yang digunakan untuk membagikan berita tersebut. 
Sukma Fatmawati, Rizky Salzabila, Galang Aulia Rizkitama, Raden Arief Nugroho, Analisis Berita Hoaks di Korpus Sosial Media Guna Mengembangkan Model "Kapak Hoaks" (Kemandirian Pembaca Menganalisis Konten Hoaks) Studi Analisis Wacana Kritis

Data (6) Postingan akun Mursyidi Pake Ie dalam akun Facebook. 8 Juni 2018

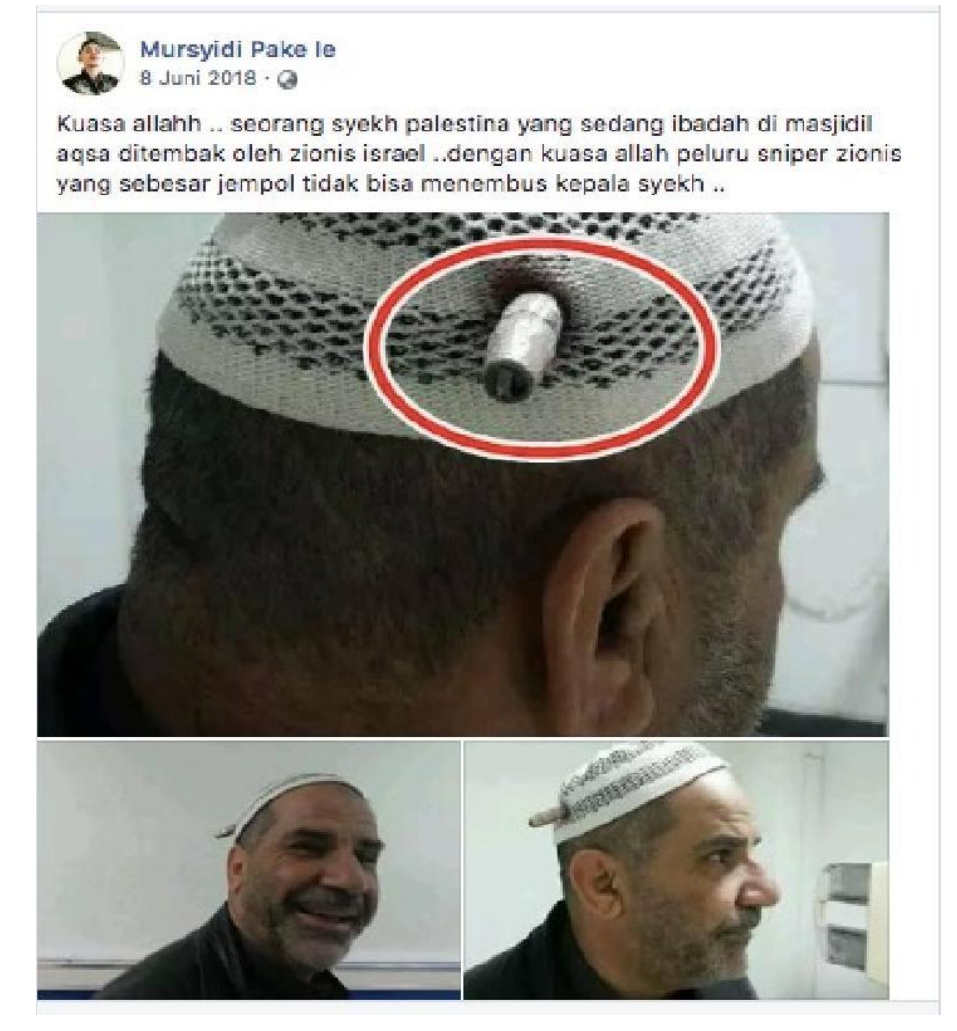

Dari berita di atas, jenis media sosial yang menggunakan untuk penyebaran berita hoaks atau berita palsu melalui jaringan sosial berupa Facebook. Unsur representasi yang ada di dalam berita tersebut adalah penulis memberikan gambar dan memberikan tambahan lingkaran merah untuk mendukung agar pembaca fokus dengan lingkaran merah yang ada di gambar namun penulis tidak memberikan secara detail tentang keadaan dan situasi kejadian tersebut. Unsur relasi yang terjadi pada berita tersebut tidak menyertakan adanya wawancara yang dilakukan sehingga tidak adanya fakta yang jelas dan isi berita tersebut tidak disertakan kapan terjadinya waktu kejadian. Unsur identitas yang ada di dalam berita tersebut yaitu penulis mencantumkan identitas narasumber, tetapi identitas penulis berita tidak tercantum. 


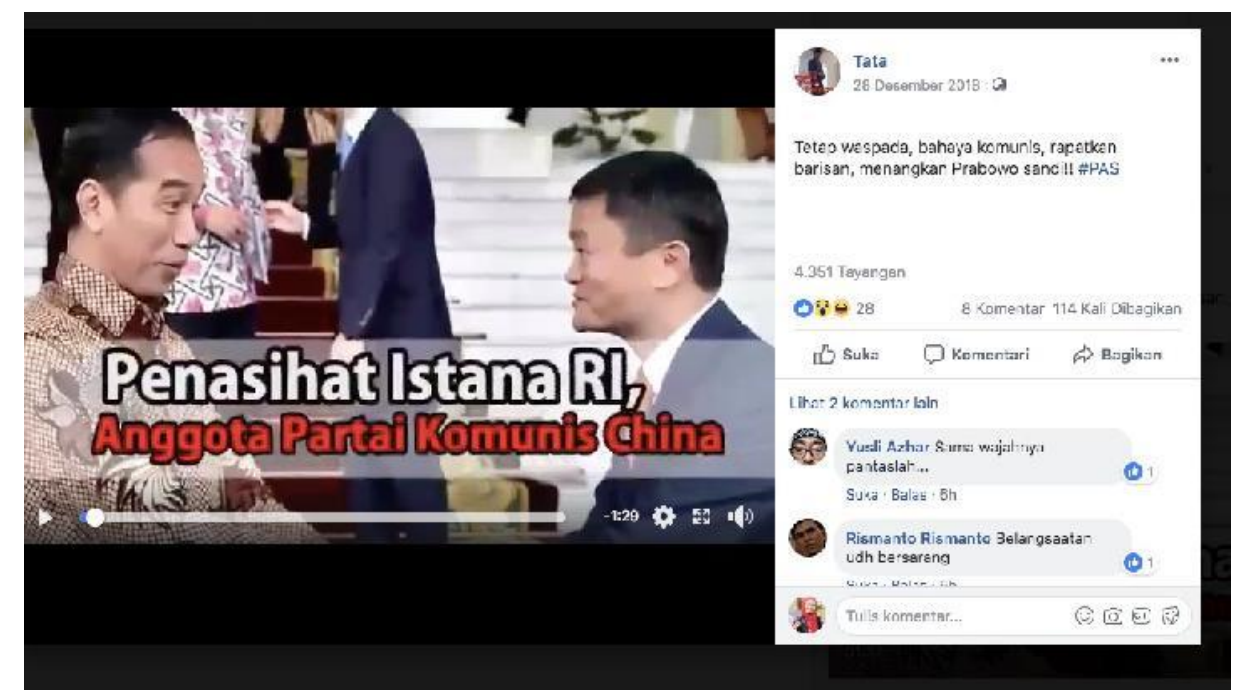

Dari data di atas media sosial yang digunakan penyebaran berita hoaks menggunakan jejaring sosial Facebook. Unsur representasi pada berita yang terjadi tidak menampilkan video asli, penulis hanya memberika screenshoot dari media youtobe. Unsur Relasi dari berita tersebut tidak diketahui kejadiannya kapan dan tidak adanya wawancara yang dilakukan oleh penulis terhadap narasumber isi berita, sehingga tidak dapat mendukung fakta yang telah tertulis di dalam berita. Unsur identitas yang ada di dalam berita tersebut yaitu tidak dicantumkannya identitas dari narasumber dan wartawan, hanya terdapat identitas dari akun jejaring sosial yang digunakan untuk membagikan berita tersebut. 
Sukma Fatmawati, Rizky Salzabila, Galang Aulia Rizkitama, Raden Arief

Nugroho, Analisis Berita Hoaks di Korpus Sosial Media Guna Mengembangkan

Model "Kapak Hoaks" (Kemandirian Pembaca Menganalisis Konten Hoaks) Studi

Analisis Wacana Kritis

Data(8) Facebook oleh Ki Suro Menggolo.

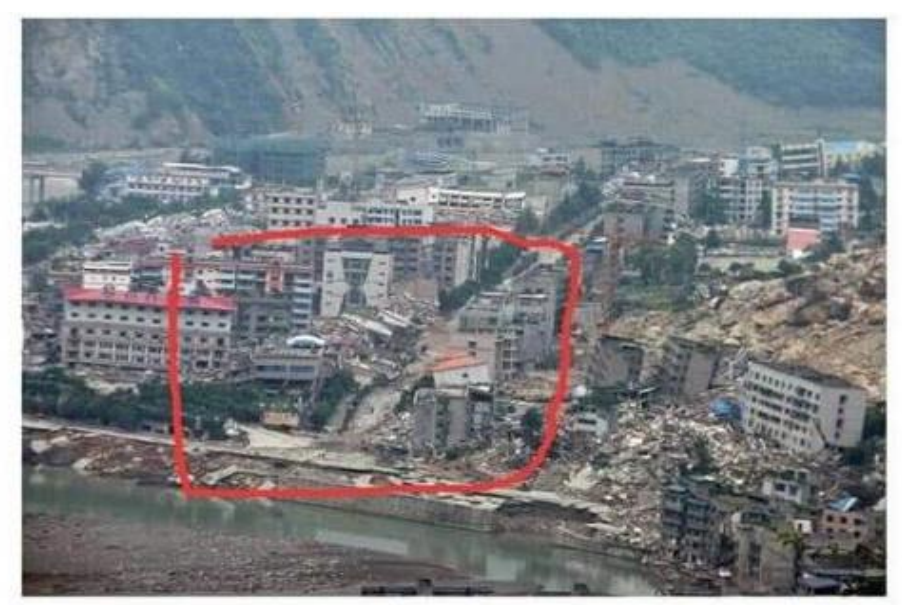

\section{Kredit foto}

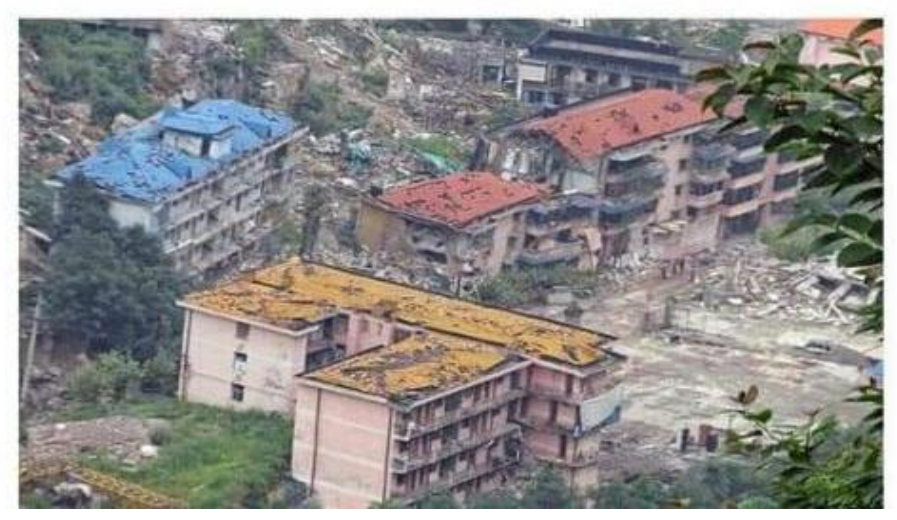

Dari berita di atas, jenis media sosial yang menggunakan untuk penyebaran berita hoaks atau berita palsu melalui jaringan sosial berupa Facebook. Unsur representasi yang ada di dalam berita tersebut adalah penulis memberikan gambar dan memberikan tambahan lingkaran merah untuk mendukung agar pembaca fokus dengan lingkaran merah yang ada di gambar namun penulis tidak memberikan secara detail tentang keadaan dan situasi kejadian tersebut. Unsur relasi yang terjadi pada berita tersebut tidak menyertakan adanya wawancara yang dilakukan sehingga tidak adanya fakta yang jelas dan isi berita tersebut tidak disertakan kapan terjadinya waktu kejadian. Unsur identitas yang ada di dalam berita tersebut tidak mencantumnya 
berapa banyak korban, narasumber dan wartawan yang jelas sehingga sudah dipastikan berita tersebut merupakan berita hoaks.

\section{Data(9) Facebook yang diunggah oleh Bagaz Borienk SilverQueen Caramel}
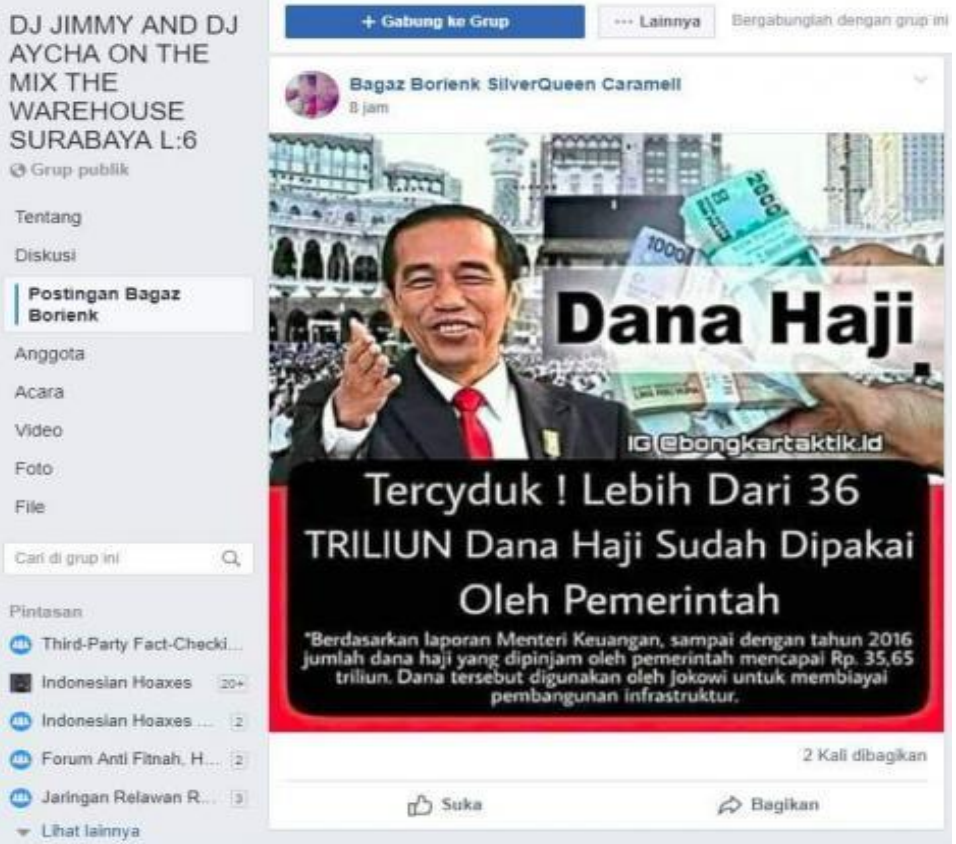

Dari data di atas, merupakan jenis media sosial berupa Facebook. Unsur representasi yang terjadi dalam berita tersebut merupakan penulis melebih-lebihkan untuk membingkai sebuah isu karena sumber dari berita tersebut tidak ditampilkan dan tampilan gambar terlalu berlebihan. Unsur relasi yang terjadi pada berita tersebut cenderung menyudutkan dan kutipan narasumber tidak disetai dengan waktu dan tempat terjadi. Unsur identitas yang ada di dalam berita tersebut merupakan penulis tidak memberikan informasi yang jelas adanya.

\section{SIMPULAN}

Berkembangnya hoaks di media sosial yang dapat menyebabkan perpecahan dan pertikaian di tengah masyarakat. Hal paling utama yang dapat dilakukan adalah dengan melakukan dorongan terhadap peningkatan kemandirian pembaca dalam menganalisis sebuah konten, terutama konten hoaks. Pembaca dapat mengamati dan 


\section{Sukma Fatmawati, Rizky Salzabila, Galang Aulia Rizkitama, Raden Arief} Nugroho, Analisis Berita Hoaks di Korpus Sosial Media Guna Mengembangkan Model "Kapak Hoaks" (Kemandirian Pembaca Menganalisis Konten Hoaks) Studi Analisis Wacana Kritis

menganalisis konten yang mereka dapatkan berdasarkan jenis media sosial, jenis berita, dan ciri ciri penulisan dari berita yang telah mereka baca dan dapatkan.

Berdasarkan hasil sampel yang peneliti dapatkan, jenis media sosial yang paling banyak digunakan sebagai wadah penyebaran berita hoaks adalah jejaring sosial (facebook, instagram, WhatsApp) yaitu sebesar 77,5\%. Jenis berita yang paling banyak digunakan sebagai berita hoaks adalah berita sosial yaitu sebesar 52,5\%. Ciri ciri berita hoaks yang paling banyak ditemukan adalah bahasa yang tidak baku sebesar $20 \%$. Ciri ciri lain yang ada dalam berita hoaks yang dapat masyarakat kenali yaitu berita hoaks tertulis dalam huruf kapital yang tidak tepat, tidak memiliki narasumber yang jelas, tidak memiliki wartawan yang jelas, penulis tidak melihat konteks, tidak ada gambar pendukung berita, antara berita dan gambar pendukung tidak berhubungan, dan waktu dan tempat kejadian tidak jelas.

\section{Ucapan Terima kasih}

Terima kasih kami sampaikan sebesar-besanya kepada Kementrian Riset, Teknologi, dan Pendidikan Tinggi (Kemenrisetdikti) yang telah membantu kami dalam pemberian dana dan dukungan terhadap penelitian kami melalui Progam Kreativitas Mahasiswa Humaniora (PKM-PSH) yang berjudul “ analisis berita hoaks di korpus sosial media guna mengembangkan model "kapak hoaks" (kemandirian pembaca menganalisis konten hoaks) studi analisis wacana kritis”. yang didanai pada tahun anggaran 2019.

\section{DAFTAR PUSTAKA}

Bugin, Burhan. (2007). Penelitian Kualitatif Komunikasi, Ekonomi, Kebijakan Publik dan Ilmu Sosial Lainnya, Edisi Kedua (Cetakan Keenam). Jakarta: Kencana, Prenada Media Group.

Eriyanto. (2001). Analisis Wacana: Pengantar Analisis Teks Media. Yogyakarta: LKiS.

Evans, J.R and Lindsay W.M. (2008). The Management and Control of Quality. (7th Edition). Ohio: Thomson South-Western.

Lattimore, dkk. (2010). Public Relations: Profesi dan Praktik. Jakarta: Salemba Humanika. 
Mahardika, Y.R. (2017, April 5). eprints. Retrieved April 15, 2018, from umm.ac.id Saputra, Wahidin \& Rulli Nasrullah. (2011). Public Relations 2.0 : Teori dan Praktik Public Relations di Era Cyber. Gramata Publishing.

Sutarya, Eva Sarah. (2018). Menghindari Hoax Broadcast Kesehatan Masa Kini. Jakarta: Universitas Islam Negeri Syarif Hidayatullah.

Syaifullah, Ilham. (2018). eprints. Retrieved April 15, 2018, from umm.ac.id Titaley, J.A. (2017). Bunga Rampai Komunikasi Indonesia. Yogyakarta: Buku Litera. 